\title{
Dasybasis elquiensis, a New Species of Horse Fly from Northern Chile (Diptera: Tabanidae: Diachlorini)
}

\author{
Christian R González
}

Instituto Entomología, Universidad Metropolitana de Ciencias de la Educación, Casilla 147, Santiago, Chile

The female of Dasybasis elquiensis, new species, is described and illustrated from specimens collected in Paso La Ternera, Elqui Province, north Chile. Its relationships to other Dasybasis species are discussed.

Key words: Dasybasis elquiensis n. sp. - Tabanidae - Neotropical region - Chile

The genus Dasybasis was erected by Macquart (1847) as a monotypic genus, including only the Australian species D. appendiculata Macquart. This genus exhibits important variation in some characters such as bare or, rarely, sparsely setose basicostas and shape of the frontal callus.

This genus is characteristic of southern temperate Neotropical fauna with 82 taxa considered valid (Fairchild \& Burger 1994). Recently, González (1999) revised the taxa included as subgeneric units of Dasybasis by Coscarón and Philip (1967a) and raised to generic status, the taxa Agelanius Rondani, Haematopotina Coscarón \& Philip, Nubiloides Coscarón \& Philip and Scaptiodes Enderlein, based on their morphological differences from Dasybasis, s.str. Four species formerly included in the genus Agelanius were transferred to the genus Acellomyia.

The genus Dasybasis ocurred in the southern Neotropical region (Fairchild \& Burger 1994) and Australian region (Daniels 1989). It is part of the most primitive group within the tribe Diachlorini predominantly ocurring in colder zones of the Neotropics and probably found in specialized habitats (Mackerras 1954, Fairchild 1969).

The genus, in a new concept (González 1999), can be recognized by the following characters: general color of the body grayish, eyes sparsely hairy and without bands. Front wide, rarely convergent at the base. Frontal callus quadrangular, touching eyes, ocellar triangle and, ocelli vestigial. Subcallus bare. Antennae with pruinosity and without dorsal pro-

\footnotetext{
Work supported by Dirección de Investigación, Universidad Metropolitana Projects GAF 97-01 and GAF $98-02$

Fax:+56-2-241.2728. E-mail: cgonza@ discovery.umce.cl Received 18 August 1999

Accepted 17 March 2000
}

jection on basal flagellomere. Maxillary palpi stout and short. Mesoscutum with longitudinal stripes reaching notopleural lobe. Wings hyaline, smoky or with clouds on the veins; with short setae on Sc, and $\mathrm{R}_{1}$ with several rows of setae. Abdomen with longitudinal stripes and triangles on tergites.

The Neotropical species of Dasybasis were monographed by Coscarón and Philip (1967a) who recognized five subgenera and eighty species. Coscarón $(1962,1969$ a, 1972, 1989) has described additional species from Chile and Argentina. Recently, González and Henry (1996) described a new species from Chile. After the revision of González (1999) the genus Dasybasis s.str. contain 68 species, three subspecies and one variety (Fairchild \& Burger 1994). Only seven species are known from immature stages (Coscarón 1969b, 1991, Coscarón \& Philip 1967b, Schwan 1989).

\section{MATERIALS AND METHODS}

The terminology follows that of McAlpine (1981). The specimens examined were collected in Paso La Ternera (2950' S, 7050') 1600 m, Elqui Province, about $500 \mathrm{~km}$ north Santiago city. This zone has a Mediterranean climate. Morphological studies were made with a stereoscopic microscope on specimens mounted on pins. In order to examine female genitalia, the abdomens were removed and macerated in hot solution of $\mathrm{KOH} 10 \%$ and subsequently mounted on slides in Canadian balsam. Drawings were made with a camera lucida.

\section{Dasybasis elquiensis n.sp.}

(Figs 1-8)

Description offemale - Length $11.5 \mathrm{~mm}$; wing 10.5 $\mathrm{mm}$. Head: eyes dark grayish, without bands, with sparse gray hairs (Fig. 1). Front pale gray, with brownish tomentum on the ocellar triangle, bearing short black hairs. Front wide, divergent at the base, frontal index 1.7. Frontal callus black, rectangular, with slight dorsal projection, touching eyes and subcallus (Fig. 2). Posterior border of the head 
gray; vertex with erect black-gray hairs. Subcallus pale gray, tomentose, with sparse, short gray hairs, darker near antennae. Clypeus and genae gray tomentose, genae with long whitish hairs, clypeus bearing whitish hairs. Beard with long whitish gray hairs. Scape of antenna light brown, gray tomentose and with short black-gray hairs on dorsal surface. Pedicel gray tomentose and with short black hairs. Basal flagellomere dark brown with slight dorsal median angle, apical flagellomeres dark brown (Fig. 3). Maxillary palpi short yellowish, bearing yellowish gray tomentum and short black-gray
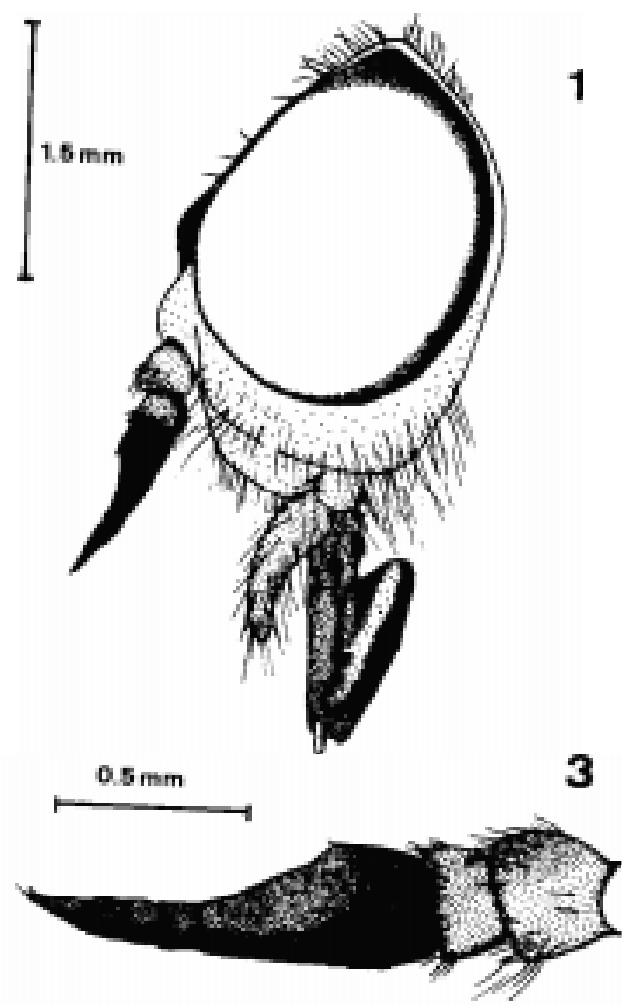

$0.5 \mathrm{~mm}$

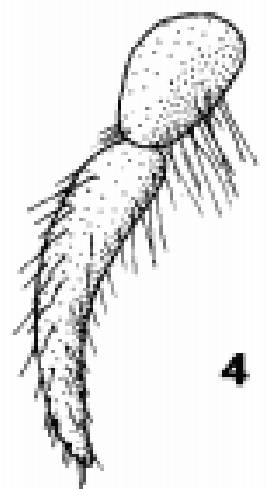

4 hairs (Fig. 4). Proboscis black, labellae black, large and fleshy (Fig. 1). Thorax: mesoscutum dark gray, with black and whitish hairs, bearing five narrow longitudinal pale stripes reaching scutellum. Notopleural lobe pale brownish gray, with long black and gray hairs. Scutellum dark gray, with short black hairs on the disc and long grayish hairs laterally that are longer than those on the mesoscutum. Pleura gray, with long grayish hairs. Legs brownish, coxae grayish. Coxae, femora and tibiae with long gray hairs. Tarsi with short black hairs. Wings hyaline, without appendix on $\mathrm{R}_{4}$. Basicosta bare.
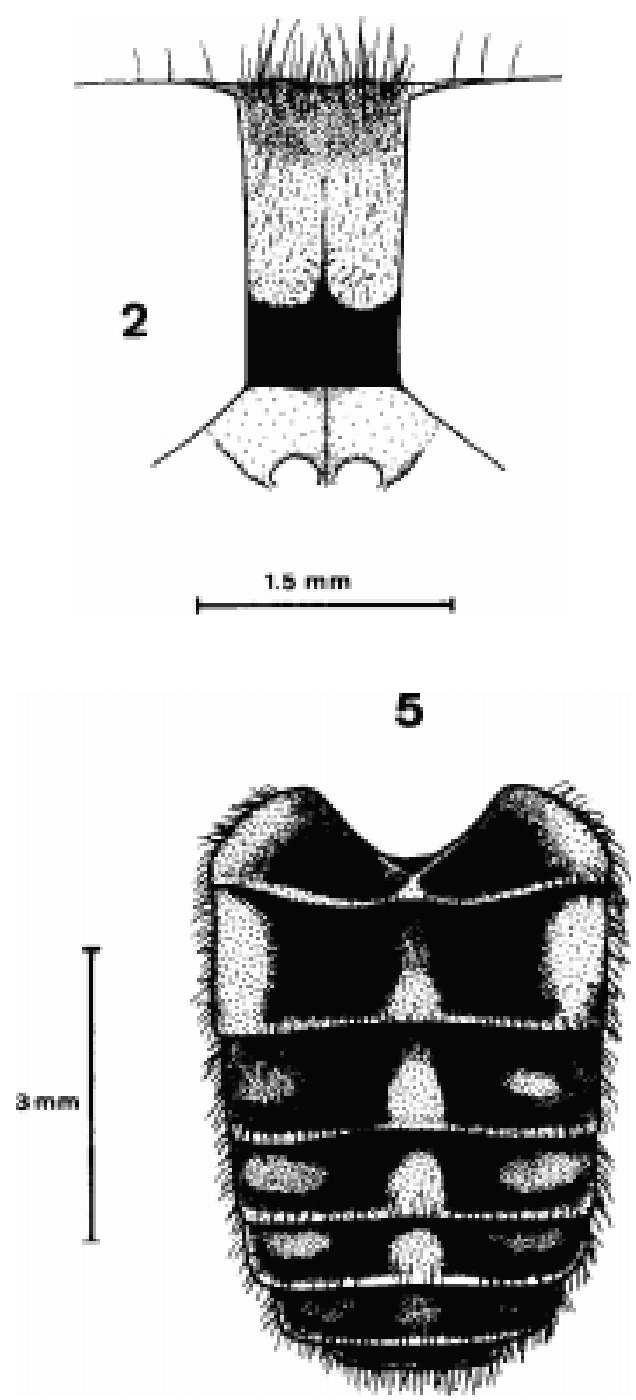

Dasybasis elquiensis n. sp. female. Fig. 1: head in side view. Fig. 2: front. Fig. 3: antenna. Fig. 4: maxillary palp. Fig. 5: abdomen in dorsal view 


\section{6}

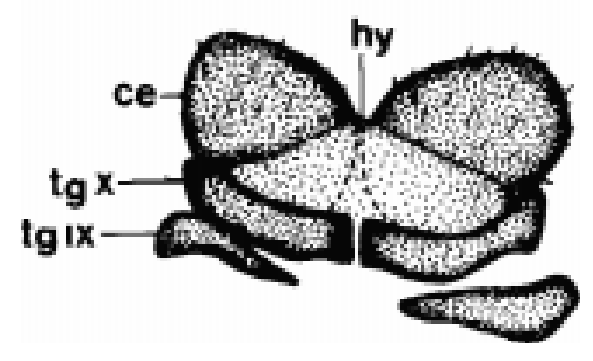

8
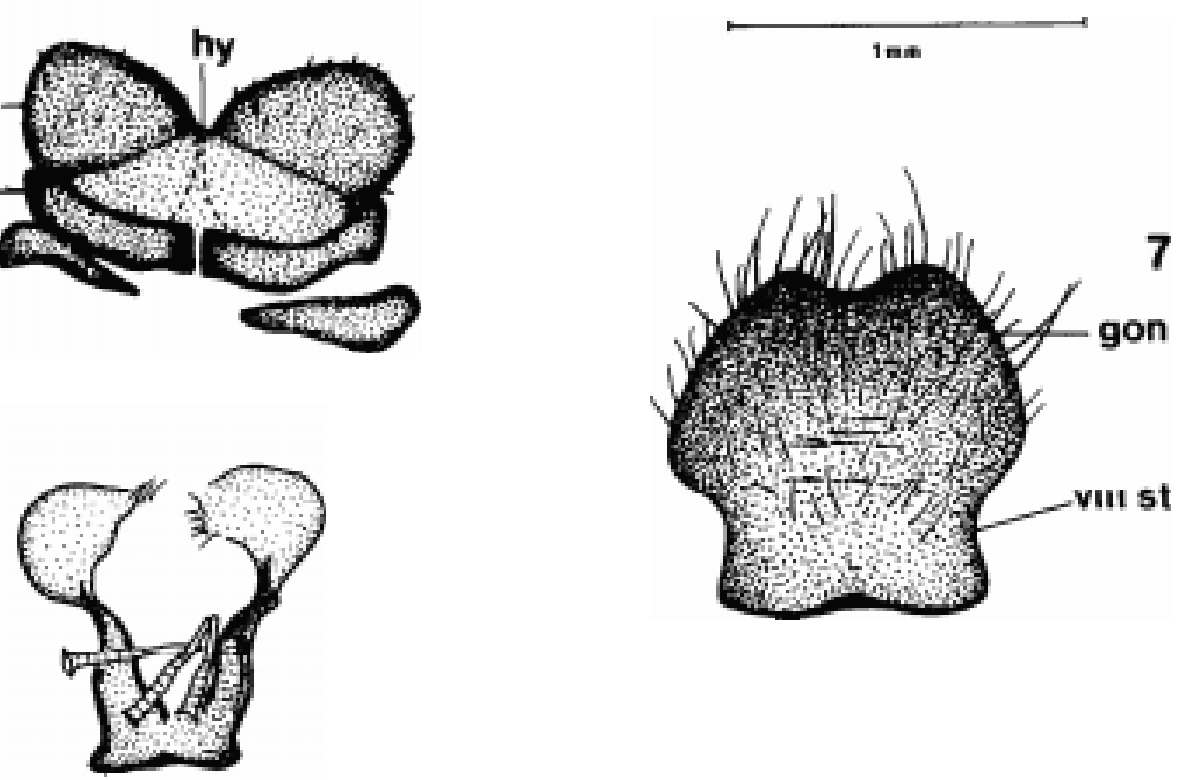

Dasybasis elquiensis n. sp. female genitali. Fig. 6: tergite IX ( $\operatorname{tg}$ IX), X ( $\operatorname{tg} X)$, cerci (ce), and hypoproct (hy). Fig. 7: gonapophysis (gon) and VIII sternite (VIII st). Fig. 8: genital fork and spermathecal ducts

Halteres dark brown. Squamae concolorous with base of wing. Abdomen: dark gray dorsally, with long, black hairs, pale brownish laterally on tergites I and II, posterior border of tergites with distinct narrow grayish hind margins and grayish hairs. Tergites I to VI with broad grayish tomentose median posterior spots. Tergites III-VI with pale grayish tomentose sublateral spots. Tergite VII with tomentum and pale grayish pilose (Fig. 5). Sternites grayish, mostly grayish haired.

Genitalia: cerci subovoidal, truncate distally, and with short hairs (Fig. 6). Tergite X subrectangular, well sclerotized (Fig. 6). Tergite IX subtriangular (Fig. 6). Gonapophysis projected distally, strongly concave, with long bristles (Fig. 7). VIII sternite with narrow and slightly concave base (Fig. 7). Genital fork with base narrow and slightly concave, with short spermathecal ducts (Fig. 8).

Male: unknown

Types: Holotype female, Chile, Elqui Province, Paso La Ternera, 19.I.1995, CR González. Paratypes: 10 females with same dates. Holotype and paratypes in Instituto de Entomología collection, Univ. Metropolitana de Ciencias de la Educación, Santiago, Chile. This species were attracted to human collectors

Etymology: the specific name is a noun in apposition taken from type locality.

\section{REMARKS}

This species exhibits generalized features characteristic of the genus Dasybasis: front wide, ocellar triangle and three ocelli vestigial, basal flagellomere of the antenna without a dorsal median angle; maxillary palpi short and stout. $D$. elquiensis is very close to $D$. caprii Coscarón \& Philip from Argentina in general appearance but $D$. elquiensis differs in the following external characters: eyes with sparse hairs, front divergent at base, without appendix on $\mathrm{R}_{4}$ and general color of the body darker. General appearance and genitalia are close to D. bejeranoi Coscarón \& Philip, but bejeranoi differs in callus shape, frontal width and, bearing only two longitudinal narrow stripes reaching the scutellum. It also has some similarity to $D$. poroma Coscarón \& Philip but poroma differs in following characters: eyes with short hairs, callus shape, front parallel-sided, and shape of the basal flagellomere and maxillary palpi.

\section{ACKNOWLEDGEMENTS}

To Dr Sixto Coscarón (University Nacional de La Plata, Argentina) for revision of the manuscript, to Dr John F Burger (University of New Hampshire, USA) for revision of the manuscript and help in editing the English version, and A Alviña for the illustrations. 


\section{REFERENCES}

Coscarón S 1962. Notas sobre tabánidos argentinos II. Sobre 2 nuevas especies de Dasybasis halladas en la zona del lago Fontana (Chubut). An Inst Nac Microbiol 1: 41-50.

Coscarón S 1969a. Ibidem VIII. Dasybasis colla una nueva especie de tábano hallado en la puna Argentina. Neotropica 15: 115-118.

Coscarón S 1969b. Datos sobre estados preimaginales de tábanos neotropicales (Diptera: Tabanidae). Rev Soc Ent Argentina 31: 19-22.

Coscarón S 1972. Datos adicionales sobre taxonomía y distribución del género Dasybasis Macquart en la región Neotropical. Rev Peruana Ent 15: 67-71.

Coscarón S 1989. A new species of Dasybasis Macquart from NW of Argentina. Mem Inst Oswaldo Cruz 84(Suppl. IV): 125-128.

Coscarón S 1991. Los estados inmaduros de siete especies neotropicales del género Dasybasis Macquart (Tabanidae, Diptera, Insecta). Acta Ent Chilena 16: 723.

Coscarón S, Philip CB 1967a. Revisión del género Dasybasis Macquart en la región neotropical (Diptera: Tabanidae). Rev Mus Argentino Cienc Nat “Bernardino Rivadavia”, Entomología 2: 15-226.

Coscarón S, Philip CB 1967b. Notas sobre biología y morfología de estadios preimaginales y descripción del macho de Dasybasis fairchildi Coscarón \& Philip. Rev Soc Ent Argentina 29: 43-51.

Daniels G 1989. Family Tabanidae. In NL Evenhuis, Catalog of the Diptera of the Australasian and
Oceanian Regions, Bishop Museum Press \& EJ Brill Honolulu and Leiden, p. 277-294.

Fairchild GB 1969. Notes on Neotropical Tabanidae XII. Classification and distribution, with keys to genera and subgenera. Arq Zool São Paulo 17: 199-255.

Fairchild GB, Burger JF 1994. A catalog of the Tabanidae (Diptera) of the Americas South of the United States. Mem Amer Ent Inst 55: 1-249.

González CR 1999. A revision of southern neotropical genera related to Dasybasis Macquart, 1847 (Diptera: Tabanidae: Diachlorini). Contributions to the knowledge of Diptera. Mem Amer Ent Inst 14: 137-194.

González CR, Henry AA 1996. Dasybasis (Agelanius) cortesi, a new species of horse fly from Chile (Diptera: Tabanidae: Diachlorini). Mem Inst Oswaldo Cruz 91: 733-737.

Mackerras IM 1954. The classification and distribution of Tabanidae (Diptera). I. General review. Aust J Zool 2: 431-454.

Macquart J 1847. Diptères exotiques nouveaux au peu connus 2e. supplément. Mem Soc Ry des Sci de l' Agr et des Arts 1846: 21-120.

McAlpine JF 1981. Morphology and terminology-adults. In JF McAlpine et al. (eds), Manual of Nearctic Diptera 1, Research Branch, Agriculture Canada (Monograph $\mathrm{N}^{\circ} 27$ ), p. 9-63

Schwan EV 1989. Untersuchungen zum Vorkommen, zur biologie und zur bekampfung von Tabaniden (Diptera: Tabanidae) in der Provinz Valdivia, Chile. PhD Thesis, Tieraztliche Hochschule Hannover, 136 pp. 